The need for speed! 10 ways that WhatsApp and instant messaging can enhance communication (and clinical care) in sport and exercise medicine

Osman Hassan Ahmed 지, ${ }^{1,2}$ Sean Carmody, ${ }^{3}$ Lewis J Walker, ${ }^{3}$ Imtiaz Ahmad ${ }^{3}$
Just as the majority of athletes are constantly seeking to get faster and better, sport and exercise medicine (SEM) clinicians need quicker and more efficient strategies to communicate with their athletes and colleagues. This drive for enhanced communication by clinicians is underscored by Ekstrand and colleagues' finding that

${ }^{1}$ Faculty of Health and Social Sciences, Bournemouth University, Bournemouth, UK

${ }^{2}$ The FA Centre for Disability Football Research, The Football Association, Burton-Upon-Trent, UK

${ }^{3}$ Medical Department, Queens Park Rangers Football Club, London, UK

Correspondence to Dr Osman Hassan Ahmed, Faculty of Health and Social Sciences, Bournemouth University, Bournemouth BH1 3LT, UK;

osman.hassan.ahmed@gmail.com 
positive internal communication between the medical team and the head coach/ manager in elite football reduced injury burden and increased player availability. Return-to-play timings can make or break a team's success in elite sport, and it is natural for clinical teams to push boundaries with regards to their speed of communication.

\section{INEVITABLE, IMPORTANT AND IMMEDIATE}

At the elite level of sport, the majority of SEM clinicians will use some form of instant messaging (IM platform) for three main purposes:

1. To discuss player findings with other staff members.

2. To plan treatment sessions.

3. To interact with athletes to reassure/advise them on their status and recovery.

Table 1 outlines examples of these, and other methods by which the modern clinician can use IM platforms to enhance their communication strategies.

\section{THE FUTURE IS ALREADY HERE}

The initial shift toward virtual communications began with the introduction of 'telemedicine', which provided clinicians in all forms of medicine with innovative platforms to communicate with their patients and colleagues. ${ }^{2}$ The emergence of the smartphone then allowed even easier access to IM platforms. WhatsApp is currently the world's popular IM platform with 2 billion users $^{3}$ and its widespread adoption has led to its integration in many medical settings, including as a simple and efficient communication tool in stroke medicine $e^{4}$ and emergency surgery. ${ }^{5}$

\section{BENEFITS OF WHATSAPP}

A key factor in the use of WhatsApp by clinicians is the widespread of WhatsApp by Millenials, with $84 \%$ of adults aged 24-35 years old in the UK using WhatsApp. ${ }^{6}$ Given that a large proportion of athletes are in this generational group, WhatsApp is clearly a platform that athletes are already comfortable in using. For many clinicians, responses to emails are too slow to share effective and up-to-date information between the medical team, coaches and athletes. WhatsApp provides the ability to communicate with many individuals at once through group chats, allows the sharing of images/videos/PDFs within the message itself and enables the sender to know when messages have been read by the recipient.

\section{CROSSING ALL THE T'S: HAVE WE?}

IM platforms are yet to be perfectly regulated for the medical setting. While WhatsApp provides end-to-end encryption (meaning that messages can only be seen by each of the users), encryption is not effective for group messages. ${ }^{7}$ The widespread sharing of sensitive patient information by doctors through IM platforms without patient consent is of concern, ${ }^{8}$ and medicolegal implications in the use of WhatsApp for clinical interactions have not been fully explored. Bullying seen in other domains of sport may also transcend into interactions through WhatsApp, as outlined by the example in table 1 . Practical guidance covering clinical interactions via WhatsApp in SEM is yet to be clearly defined, and the role that WhatsApp group moderators can play in communication via WhatsApp also requires more exploration. Notably, the nuances associated with the use of WhatsApp and other IM platforms for medical communication in elite sport are not fully understood. The nature of the relationships that SEM clinicians have with uninjured athletes in their squads is clearly different to that of a general clinician working with members of the public. As such, the nature of SEM clinician-athlete communication via WhatsApp is also likely to be different, and consideration how to achieve professionalism in this setting is required.

\section{AN EVOLVING REALITY}

The current covid-19 pandemic has put an increased spotlight on embracing telehealth approaches across all forms of healthcare, including SEM. WhatsApp may be the platform of choice for many SEM clinicians now, but history has indicated that newer and better platforms are always around the corner. Rather than become wedded to the use of just one specific IM platforms, SEM clinicians should consider how they can best use any new communication platforms which emerges. Adhering to existing best-practice communication recommendations from the respective Professional,
Statutory and Regulatory Bodies, in conjunction with staying abreast of technological advances in the field of communication, will help to futureproof clinicians with these technologies.

Twitter Osman Hassan Ahmed @osmanhahmed

Contributors OHA drafted the initial version of this manuscript and IA and SC modified the subsequent versions. All authors approved the final version of the manuscript.

Funding The authors have not declared a specific grant for this research from any funding agency in the public, commercial or not-for-profit sectors.

Competing interests None declared.

Patient consent for publication Not required.

Provenance and peer review Not commissioned; externally peer reviewed.

(C) Author(s) (or their employer(s)) 2020. No commercial re-use. See rights and permissions. Published by BMJ.

$$
\text { A) Check for updates }
$$

To cite Ahmed OH, Carmody S, Walker LJ, et al. Br J Sports Med 2020;54:1125-1135.

Accepted 9 April 2020

Published Online First 29 April 2020

Br J Sports Med 2020;54:1125-1135.

doi:10.1136/bjsports-2019-101707

\section{ORCID iD}

Osman Hassan Ahmed http://orcid.org/0000-00021439-0076

\section{REFERENCES}

1 Ekstrand J, Lundqvist D, Davison $\mathrm{M}$, et al. Communication quality between the medical team and the head coach/manager is associated with injury burden and player availability in elite football clubs. $\mathrm{Br}$ J Sports Med 2019:53:304-8.

2 Graziano F, Maugeri R, lacopino DG. Telemedicine versus WhatsApp: from tradition to evolution. Neuroreport 2015;26:602-3.

3 Two Billion Users - Connecting the World Privately, 2020. Available: https://blog.whatsapp.com/10000666/ Two-Billion-Users--Connecting-the-World-Privately [Accessed 23rd Mar 2020].

4 Calleja-Castillo JM, Gonzalez-Calderon G. WhatsApp in stroke systems: current use and regulatory concerns. Front Neurol 2018;9:388.

5 Johnston MJ, King D, Arora S, et al. Smartphones let surgeons know WhatsApp: an analysis of communication in emergency surgical teams. Am J Surg 2015:209:45-51.

6 Share of WhatsApp users in the United Kingdom, 2018 Available: https://www.statista.com/statistics/611208/ whatsapp-users-in-the-united-kingdom-uk-by-agegroup/ [Accessed 19th Jan 2020].

7 Are WhatsApp group chats vulnerable to spying despite end-to-end encryption? 2018. Available: https://medium.com/@haniahshafi/are-whatsappgroup-chats-vulnerable-to-spying-despite-end-to-endencryption-ab0e522fa8d9 [Accessed 19th Jan 2020].

8 Opperman CJ, Janse van Vuuren M, van Vuuren MJ. WhatsApp in a clinical setting: the good, the bad and the law. S Afr J Bioeth Law 2018;11:102-3. 


\section{Editorial}

Table 1 Recommendations and practical examples for the use of WhatsApp in SEM

\begin{tabular}{|c|c|c|}
\hline $\begin{array}{l}\text { Nature of } \\
\text { recommendation }\end{array}$ & Recommendations for use of WhatsApp in SEM & Practical example \\
\hline Functional & $\begin{array}{l}\text { Embrace functionality } \\
\text { WhatsApp allows files, photos and videos to be shared. Could these enhance your } \\
\text { communication with athletes and staff? }\end{array}$ & $\begin{array}{l}\text { Physiotherapist in professional cricket: } \\
\text { Event: Message received from upset player with setback in ACL rehabilitation. } \\
\text { Solution: Short voice note shared with player for reassurance rather than sending a message. }\end{array}$ \\
\hline Functional & $\begin{array}{l}\text { Recognise limitations } \\
\text { Will a phone call or a face-to-face meeting will be more appropriate than an instant } \\
\text { message? Verbal and non-verbal communication are the cornerstone of effective } \\
\text { medical communication. }\end{array}$ & $\begin{array}{l}\text { Doctor in professional football: } \\
\text { Event: Receives MRI scan showing significant abnormality for a player. } \\
\text { Solution: Due to understandable anxieties from the player relating to the scan, the Doctor arranges to } \\
\text { meet the player in person to discuss the MRI result. }\end{array}$ \\
\hline Functional & $\begin{array}{l}\text { Educate clearly } \\
\text { Using infographics and emojis on WhatsApp can help distribute key messages to } \\
\text { athletes, leading to positive and lasting behavioural change. }\end{array}$ & $\begin{array}{l}\text { Physiotherapist in a national sporting organisation: } \\
\text { Event: Outbreak of gastroenteritis within the national judo squad. } \\
\text { Solution: Shares concise information on hand hygiene strategies with the judo squad via a WhatsApp } \\
\text { group message with emojis. }\end{array}$ \\
\hline Functional & $\begin{array}{l}\text { Communicate rapidly } \\
\text { Optimise information sharing by sending group WhatsApp messages regarding changes } \\
\text { to session planning and meeting times (rather than emails or individual phone calls). }\end{array}$ & $\begin{array}{l}\text { Video analyst in professional football: } \\
\text { Event: Coach brings team meeting forward by } 1 \text { hour unexpectedly. } \\
\text { Solution: Video analyst messages the staff and players WhatsApp groups about this change to the } \\
\text { schedule and prompts everyone to share this message. }\end{array}$ \\
\hline Professional & $\begin{array}{l}\text { Set boundaries } \\
\text { Consider whether to set boundaries with your players and colleagues around when and } \\
\text { how you will be accessible through WhatsApp. }\end{array}$ & $\begin{array}{l}\text { Sports Therapist in semi-professional rugby: } \\
\text { Event: Change to work-life balance by undertaking additional caring responsibilities for family. } \\
\text { Solution: Informs coaches/players that non-emergency messages will be replied to during traditional } \\
\text { working hours (09:00-18:00). }\end{array}$ \\
\hline Professional & $\begin{array}{l}\text { Administer effectively } \\
\text { Identify your rationale for using WhatsApp groups, and consider amending the group } \\
\text { administrators if this will streamline communication. }\end{array}$ & $\begin{array}{l}\text { Doctor in professional football: } \\
\text { Event: Staff/player WhatsApp group used for logistics frequently goes off on irrelevant tangents. } \\
\text { Solution: Speaks to the head coach, and group administrators are changed so only staff can post } \\
\text { messages. }\end{array}$ \\
\hline Professional & $\begin{array}{l}\text { Enhance engagement } \\
\text { Consider using WhatsApp to overcome geographical restrictions and time constraints to } \\
\text { facilitate athlete engagement with rehabilitation and performance. }\end{array}$ & $\begin{array}{l}\text { Physiotherapist in amateur hockey: } \\
\text { Event: Limited face-to-face contact with injured athletes consistently led to suboptimal return to play } \\
\text { outcomes. } \\
\text { Solution: Introduces WhatsApp to discuss rehabilitation programmes, monitor exercise technique and } \\
\text { encourage athletes within the squad. }\end{array}$ \\
\hline Ethicolegal & $\begin{array}{l}\text { Stay legal } \\
\text { Abide by your PSRB guidelines at all times to always use WhatsApp in an ethical and } \\
\text { professional manner. }\end{array}$ & $\begin{array}{l}\text { Doctor in professional ice hockey: } \\
\text { Event: Receives a video from a relative which they find funny but may be considered offensive. } \\
\text { Solution: They are aware of their PSRB obligations and therefore does not send it to the other staff } \\
\text { members on the medical/coaching staff group. }\end{array}$ \\
\hline Ethicolegal & $\begin{array}{l}\text { Be kind } \\
\text { IM platforms potentially provide a stage to engage in bullying. Take proactive steps } \\
\text { to ensure conduct on WhatsApp meets the standards of your organisation's policy on } \\
\text { bullying and communication. }\end{array}$ & $\begin{array}{l}\text { Sport Scientist in professional rugby: } \\
\text { Event: Notices a coach repeatedly making disparaging comments about the club physiotherapist (who is } \\
\text { also in the WhatsApp group). The physiotherapist is affected by these comments. } \\
\text { Solution: Highlights this issue to their line manager, and steps are taken to address the matter and } \\
\text { prevent its reoccurrence. }\end{array}$ \\
\hline Ethicolegal & $\begin{array}{l}\text { Keep documenting } \\
\text { While WhatsApp is useful for rapid medical communication, key points should be } \\
\text { recorded and saved in the athlete's medical records to facilitate continuity of care. }\end{array}$ & $\begin{array}{l}\text { Sports Therapist at a semi-professional football club: } \\
\text { Event: Exchange of WhatsApp messages with a player regarding their ankle injury. } \\
\text { Solution: Updates coaches on the recovery of the athlete and summarises the discussion in the athlete's } \\
\text { medical records. }\end{array}$ \\
\hline
\end{tabular}

